\title{
‘IREP EN KEMET’ PROJECT: CREATING THE CORPUS OF WINE IN ANCIENT EGYPT
}

\author{
M.R. Guasch-Jané a, *, S. Fonseca a, M. Ibrahim a \\ a Faculty of Social \& Human Sciences, Nova University of Lisbon, Av. De Berna 26-C, 1069-061 Lisbon, Portugal - (Guasch, \\ Fonseca, Ibrahim).wineancientegypt@gmail.com
}

KEY WORDS: Ancient Egypt, Viticulture, Wine, Tomb scenes, Wine jars, Inscriptions, Legacy, Database, Website

\begin{abstract}
:
Presented are the research objectives of the project 'Irep en Kemet', Wine of Ancient Egypt, and the content of the website. This research project aims at documenting the complete corpus of wine in ancient Egypt and analysing the data (iconography, textual sources and artefacts) to unveil the importance of the ancient Egyptian wine culture legacy in the Mediterranean region. At this stage, a bibliographical researchable database relevant to wine, viticulture and winemaking in the ancient Egypt has been completed, a scene-detail database for the viticulture and winemaking scenes in the Egyptian tombs has been recorded, and the collected data will be studied and analysed. Our main goal is to provide scholars with a complete, comprehensive archaeological and bibliographical database for the scenes of viticulture and winemaking depicted in the Egyptian tombs throughout the ancient Egyptian history. The project's website (under construction) will include all the collected data, the study and analysis, as well as the results of our research.
\end{abstract}

\section{THE ‘IREP EN KEMET’ PROJECT}

\subsection{Introduction}

The 'Irep en Kemet' research project's main goal is to document and analyse, for the first time, the complete corpus of viticulture and winemaking scenes depicted on the walls of the ancient Egyptian private tombs, being the most important data to study the history and legacy of wine production in the Mediterranean region. The traditional European wine elaboration method, which has been used for centuries in the southern European countries like France, Spain, Italy, Portugal or Greece, is considered to come from ancient Greece and Rome. However, the iconographical, archaeological and textual sources from ancient Egypt confirm that the wine was already produced there in the third millennium BC. The scenes represented on the walls of Egyptian private tombs show how the different steps in the elaboration of wine are very similar to the traditional European method. Although several studies and researches were undertaken to resume the viticulture and winemaking in ancient Egypt (Lerstrup, 1992; Lesko, 1996; James, 1996; Tallet, 1998; Murray, 2000; Guasch-Jané, 2008), it has not been compiled and analysed in depth until now. 'Irep en Kemet' is a three-year scientific project (2011-2013) that is directed by Dr. Maria Rosa Guasch Jané at the Faculdade de Ciencias Sociais e Humanas of the Universidade Nova in Lisbon (Portugal), and funded by the Fundação para a Ciência e a Tecnologia (FCT) of the Portuguese Ministry of Science and Education.

The research team consists of Sofia Fonseca, Archaeologist and Egyptologist, Mahmoud Ibrahim, Egyptologist and Linguist and Maria Rosa Guasch Jané, Pharmacist and Egyptologist.

This paper presents the current stage of our research and the database we are developing, which will be accessible in the project's website, together with the highlights of the research project.

\subsection{Wine in ancient Egypt}

The oldest and most extensive documentation about the viticulture and wine production comes from ancient Egypt. In Egypt, wine was a prestigious product consumed mainly by the upper classes and the royal family. Wine was offered in the daily temple rituals, in funerary offerings (Meyer, 1986) and used in medical treatments. Viticulture and winemaking scenes are depicted on the walls of the private tombs from the Old Kingdom (2575-2150 BC) through the Graeco-Roman times (332 BC-395 AD). Thanks to these scenes, we have information about how the wine was made; the scenes showing that the procedures are very similar to the traditional European method (Guasch-Jané 2008; Guasch 2010).

\subsection{Wine jars and their inscriptions}

Since the Predynastic Period (4000-3100 BC), wine jars were placed in the Egyptian tombs as funerary offerings. During the New Kingdom Period (1539-1075 BC), wine jars (amphorae) were inscribed in hieratic to indicate: the year, the name of the product (irp (Erman, 1926) or shedeh (Erman, 1930)), the quality, the provenance, the property (royal or private) and the name and title of the wine-maker (Figure 1).

The inscription on the amphora (Journal d'Entrée 62303, Cairo Museum (Figure 1)) from Tutankhamun's tomb (KV 62) at Thebes, reads: "Year 4, wine from the Estate of Aten, in the Western River, chief vintner Nen" (Černy, 1965). As Figure 1 shows, the clay seal of this amphora is broken and it is open on the upper part. Like the labels in the modern bottles of wine, the inscriptions on the New Kingdom wine jars give us information about the harvest and wine production (Guasch, 2010).

These inscriptions on the amphorae reveal that the ancient Egyptians considered this information relevant and necessary to be able to distinguish between wines. It was extremely important to know the vintage and the provenance of the product. 


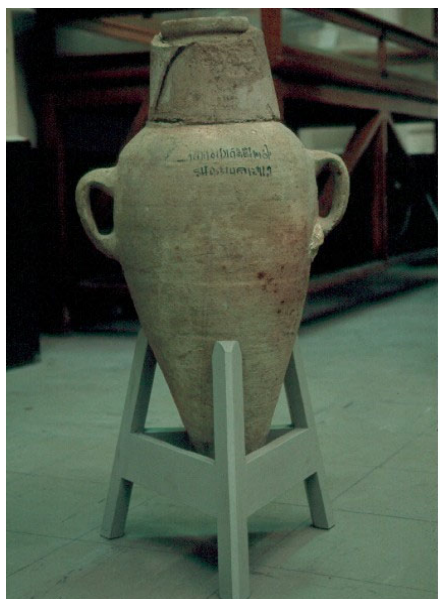

Figure 1. Tutankhamun's amphora JE 62303. Copyright: Maria Rosa Guasch Jané, with permission of the Cairo Museum

However, it is curious that no mention was made concerning the colour of wine, either white or red, on the inscriptions or any other documents.

The symbolism of the Egyptian wine was based on its red colour, not only because of the relation established between wine and the blood of the resurrection god Osiris, but also because of the reddish colour of the River Nile during the annual flood -with ferruginous sediments coming from the Ethiopian mountains-, when the harvest time for grapes started (Poo, 1986; 1995). In the papyrus of the royal scribe Nakht at the British Museum in London (BM 10471), a vine is leading to the nose of god Osiris as a symbol of resurrection. This symbolism is still in use in Coptic iconography today.

The Egyptian mythology related the wine only to the red colour, and no textual references to white wine -or to red wine- from the Dynastic period (3100-343 BC) have been found in Egypt up to now. The first mention of white wine in Egypt is from Athenaeus of Naucratis, who lived during the 3rd century BC, in his book The Deipnosophistae, where he explains that Mareotis wine, in the area of Lake Mariut near Alexandria, was "excellent, white and enjoyable, aromatic..." (Athenaeus, 1961).

In order to study the kind (colour) of the wines that were made in ancient Egypt, an analytical method (Guasch-Jané, 2004; 2008) for archaeological residues of wine was developed using the liquid chromatography mass spectrometry in tandem (LC/MS/MS) technique. Two compounds were identified in archaeological residue samples from Tutankhamun's amphorae: tartaric acid, as grape marker, and syringic acid derived from malvidin, the latter being the main compound responsible for the red colour of grapes and wines, as red grape marker (Guasch-Jané, 2004; 2006a,b). The results of analysing residue samples from Tutankhamun's amphorae revealed that in ancient Egypt red and white wines were given the name irp (GuaschJané, 2006b; 2008).

The analytical results added new information to the inscription on the amphorae: about the type of wine they contained. There was a red wine in Tutankhamun's amphora Cairo Museum $J E$ 62314 (Guasch-Jané, 2006b; 2008) with the inscription "Year 9, wine of the Estate of Aten of the Western River, chief vintner Khaa", and a white wine was contained in Tutankhamun's amphora JE 62316 (Guasch-Jané, 2006b; 2008) with the inscription "Year 5, wine of the Estate of Tutankhamun, ruler of Thebes in the Western River, chief vintner Khaa".

The results of these analyses also confirm that in Egypt, during the New Kingdom Period, three kinds of grape products were made (Guasch-Jané, 2008): red wine, white wine and the shedeh, a red wine with a different preparation.

The origin and nature of the shedeh, which has no translation, was a mystery since a century ago, with pomegranates or grapes having been proposed as a raw material. According to Papyrus Salt 825 (BM 10051) of the Late Period (715-332 BC), the only text found so far that mentions the elaboration of the shedeh, it was filtered and heated; nevertheless, due to a damage in the Salt papyrus, the botanical source of shedeh remained unknown (Derchain, 1965; Tallet, 1995; Guasch-Jané, 2008; Tallet 2010). The results of analysing a sample of a residue from the shedeh amphora found in Tutankhamun's Burial chamber (JE 62315, Carter no. 206), bearing the inscription "Year 5, shedeh of very good quality of the Estate of Aten of the Western River, chief vintner Rer" (Černy, 1965) confirmed that shedeh was a red grape wine (Guasch-Jané, 2006a; 2008).

Recent research suggested the use of the three amphorae found in Tutankhamun's Burial chamber (containing a red wine, a white wine and shedeh, respectively) were for the King's threestep resurrection ritual (Guasch-Jané, 2011).

\section{VITICULTURE AND WINEMAKING SCENES}

\subsection{Scenes in the Egyptian tombs}

The reliefs and paintings in the ancient Egyptian private tombs depict the different steps of viticulture and winemaking including grape harvest, treading, pressing, fermentation, closing the jars, stamping and labelling the jars, and finally storing the jars in the cellar (Murray, 2000; Guasch-Jané, 2008). In the scene from Nakht's tomb (Figure 2) at Thebes, dating to the Eighteenth Dynasty (1539-1292 BC), the grape harvest and winemaking are represented. To the right, the scene shows two workers picking up the red grapes by hand and putting them in baskets. To the left, a group of four men are pressing the grapes in a vat with their feet and, besides this, there is a man taking the red juice (the must) that flows out. On the top, the amphorae are sealed with a mud stopper.

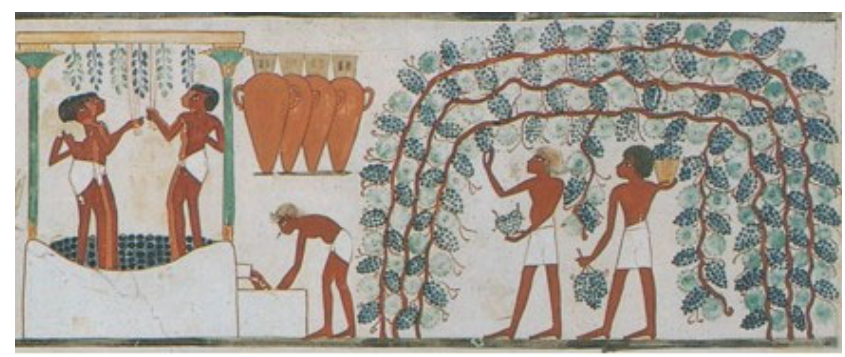

Figure 2. Nakht's tomb (TT 52) in Sheikh Abd El-Qurna, Thebes

Regarding the presence of white grapes in the iconography, it is still under discussion. It has been suggested that a tomb from Deir El-Bersheh of the Middle Kingdom Period (1975-1640 $\mathrm{BC}$ ) may show the production of white wine, since the pressing scene directly follows the harvesting scene where greenishcoloured grapes could be represented (Montet, 1913; Murray, 2000).

The elaboration of the shedeh represented in the scenes is also doubtful, and there is a unique reference from the tomb of Baqet III (no. 15) in Beni Hassan that might show a filtering and a 
heating process (Tallet, 1995).

Our project starts the documentation of the corpus of wine in ancient Egypt with the viticulture and winemaking scenes, not only because of the extensive information they provide, but also for many aspects that are less studied. The types and forms of the vines that are represented in the scenes, and the different heights of the vine tree or its shape are still not fully studied and classified. The same for the workers involved in the grape harvest, the way they picked the grapes as well as the kind of baskets they used for transporting the grapes to the press.

Furthermore, the type and material of the press (or deposit) where the grapes were treaded needs to be studied in-depth, because these scenes are the only references as no archaeological evidence has been found. Another aspect we aim to study is the second extraction of the grapes juice (and colour) using a sack-press.

The fermentation process and the closing of the wine-jars, or the strict control of closing and labelling wine-jars during the New Kingdom Period, revealed by the amphorae and their inscriptions, are even more interesting aspects to be investigated.

\subsection{Documenting the scenes}

Our team is developing a database in two different parts: the bibliography and the scenes of viticulture and winemaking. We are documenting all the viticulture and winemaking scenes in the Egyptian tombs, including the iconography and the texts associated to the images (Fonseca, 2012). The different elements of the grape harvest and wine production that are depicted in the tombs will be analysed, classified and then compared to the traditional European winemaking method.

The research methodology includes the bibliographical database with all the books, articles, websites and on-line articles as well as existing databases related to wine, viticulture and winemaking in ancient Egypt, and the scenes database with all the iconography and texts related to viticulture and winemaking in the Egyptian private tombs from all archaeological sites in Egypt (Fonseca, 2012).

The scenes will be classified according to type, condition, image, period and name of the tomb owner. The wine production and any representation of the three kinds of wines (white wine, red wine and shedeh) will be investigated.

The hieroglyphic texts accompanying the scenes will be studied, categorized, and the translation and commentary will be included.

Moreover, the titles of the owners of these tombs having viticulture and winemaking scenes will be studied to unveil the existence of wine-makers, and to know the different specific titles related with wine production.

\section{THE PROJECT'S WEBSITE}

\subsection{Bibliographical database}

The project's website will first include the database with the bibliography related to wine, viticulture and winemaking.

The bibliographical database, which has now more than 180 entries, see example in Figure 3, includes the following items about each reference: serial number, type of article/book, authors, title, website, online link, periodical/ journal/ encyclopaedia/ dictionary, edition, editors, pages, plates/ plans, publisher, place of publication, year of publication, author abbreviation and remarks (Fonseca, 2012). It is being recorded in Excel Sheet and presented by Filemaker Pro11 software.

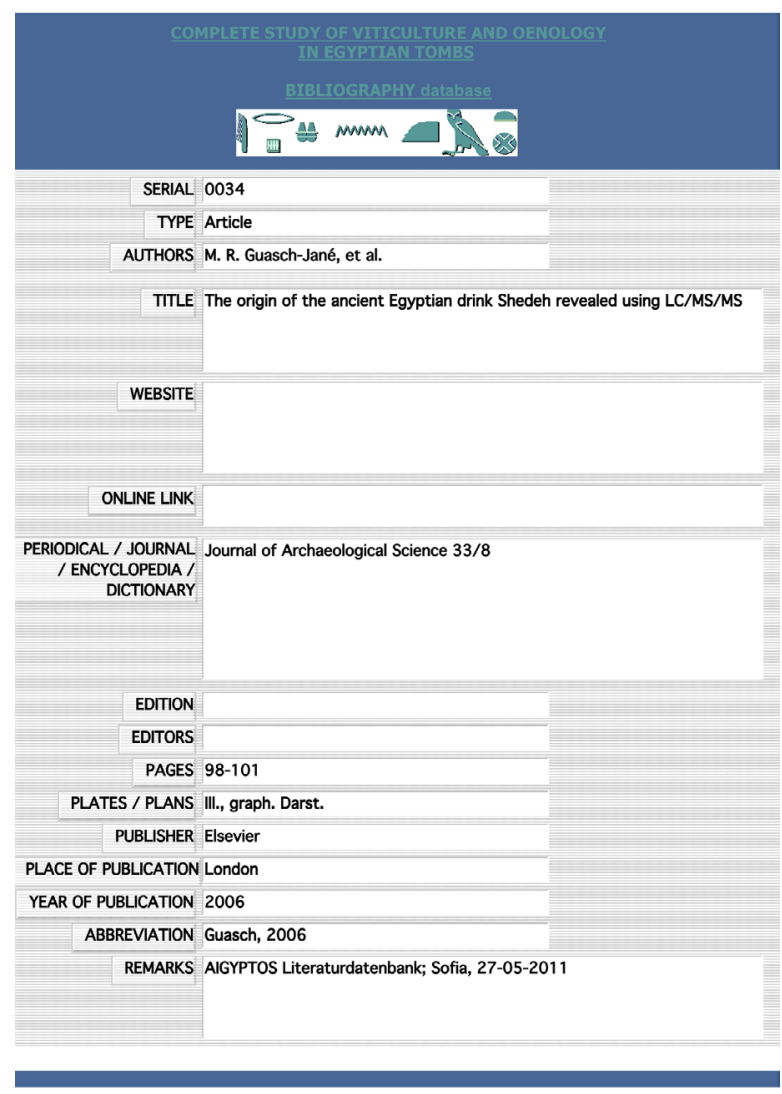

Figure 3. Bibliographical database

\subsection{Scene-detail database}

The database of the scenes of viticulture and winemaking in the ancient Egyptian private tombs (see Figure 4), in process, will include the following items about each scene (see Figure 5): record number, scene description with the different steps according to the theme, that is, viticulture or winemaking. The steps represented in the viticulture scenes include: vinery, taking care of the vine, grape harvest and counting the baskets. In the winemaking scenes, the steps represented are: transporting grapes to a press, pressing grapes, heating and filtering, pressing the remains in a sack press, filling wine jars, fermentation, offerings to goddess Renenutet, wine tasting, sealing the wine jars, labelling wine jars, counting wine jars, transporting wine jars to a cellar, refrigeration during fermentation, and storing wine jars in a cellar.

The scene-detail database (Figure 5) will also include: scene details, annotations, scene type and scene condition, text (inscriptions and translation) and image/photo.

Moreover, the scene database (Figure 6) will include: dating (period, dynasties and kings), location which includes: a) provenance with governorate, archaeological site, tomb name and number and location inside the tomb; b) present location, with same as provenance, if it's a museum then location inside the museum and inventory number, and others if it's not a museum. Finally, the tomb information (type of tomb, tomb's owner and name and titles of the tomb's owner) will be included. At the end, the bibliographical references related to the scene will be listed. 
The data is being recorded in Excel Sheet and presented by Filemaker Pro11 software.

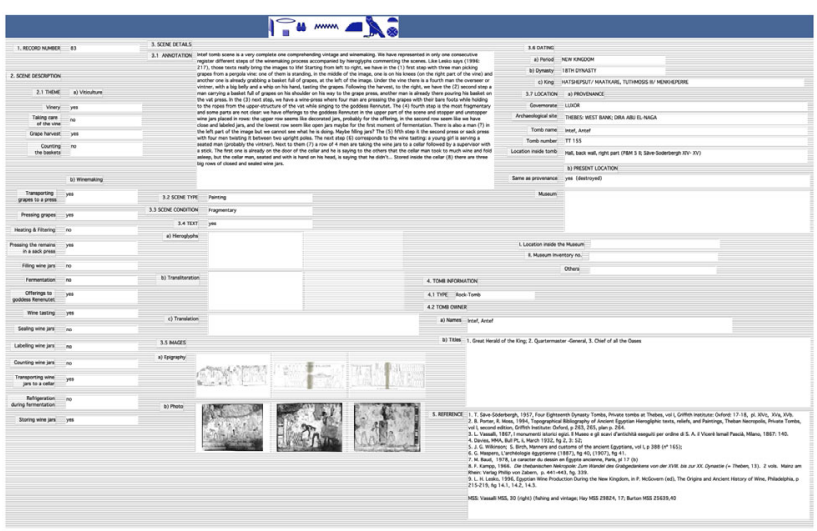

Figure 4. Global image of the scene database. Copyright (photos): Griffith Institute, University of Oxford, and Abteilung Ägyptologie, FB III, Universität Trier

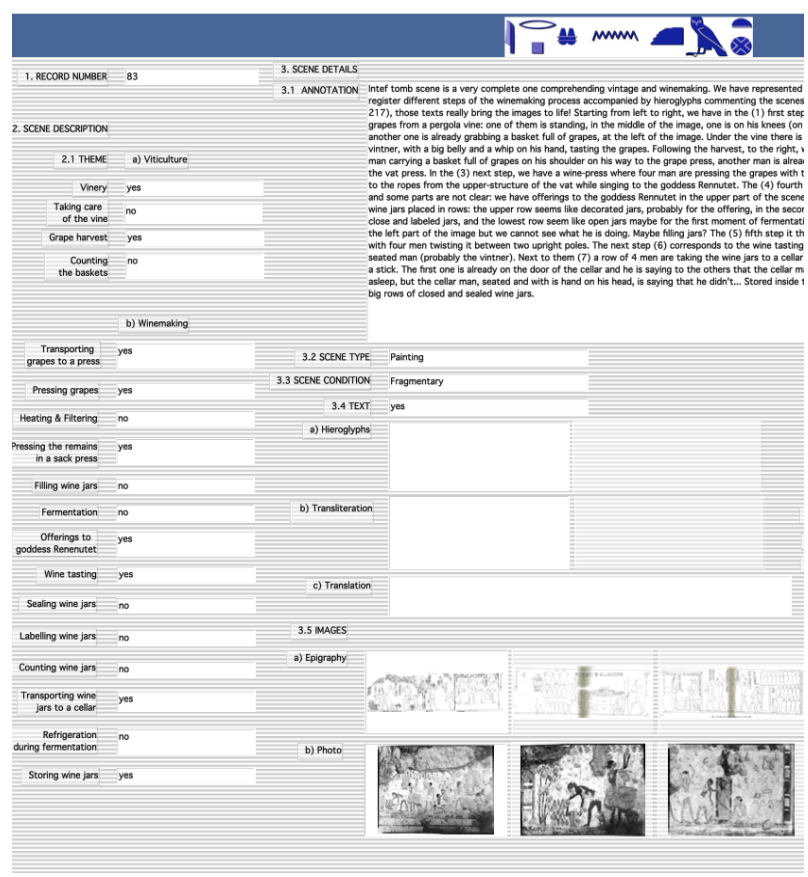

Figure 5: Scene database, detail (left side). Copyright (photos): Griffith Institute, University of Oxford, and Abteilung Ägyptologie, FB III, Universität Trier

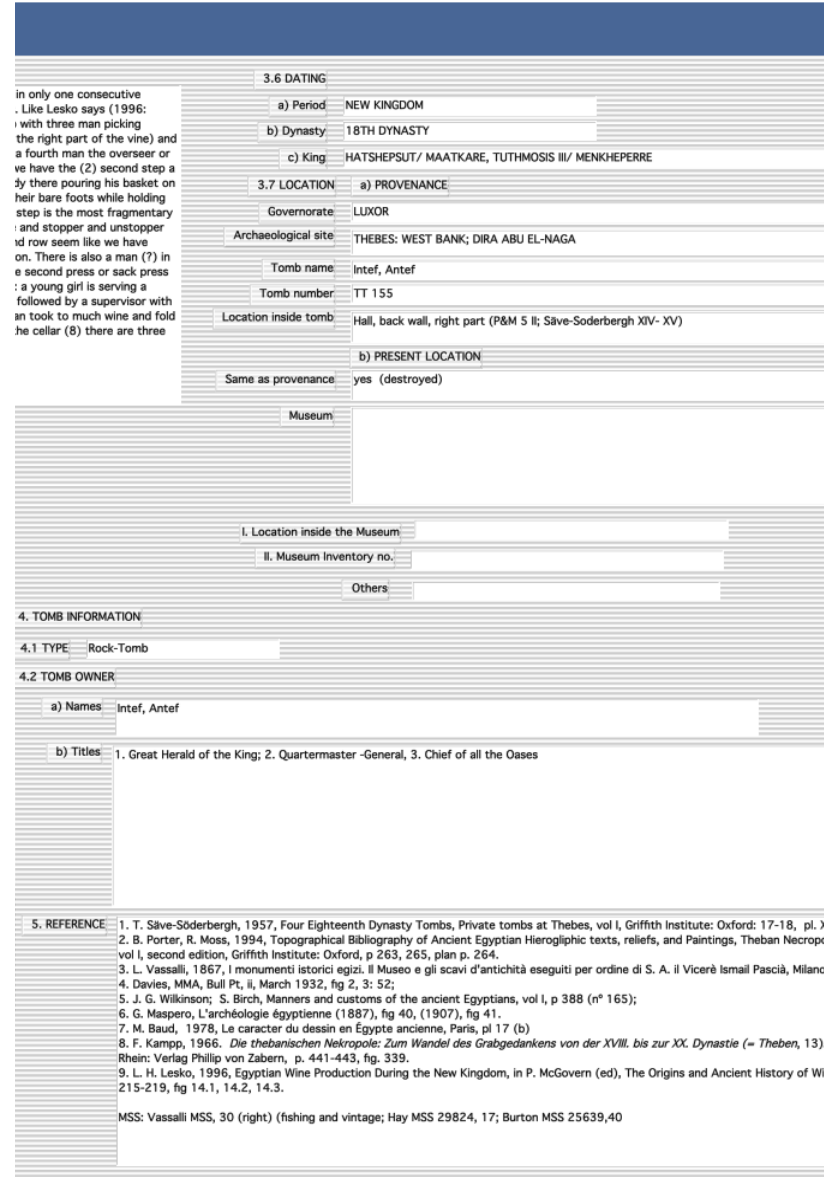

Figure 6: Scene database, detail (right side)

\subsection{Technology transfer and dissemination}

Besides the database with the corpus of scenes of viticulture and winemaking and the bibliography at the first stage, the project will develop a website, which will include all the material related to the research and the scientific and non-scientific dissemination of the results. The research manuscripts that we plan to publish in international peer-reviewed journals with the results of the scientific research will be included in the website. Articles presenting the results and addressed to the public will be also included in the website, as well as articles in journals specialised in Egyptology, archaeology or oenology, magazines and in the mass media. Furthermore, the communications in congresses presenting the research results of this project will be posted in the website, as well as conference proceedings, and lectures to the scientific community and to the general public.

\subsection{Further research}

We plan to extend our research to the other aspects related to wine that are represented in the ancient Egyptian iconography: the daily life scenes of wine drinking in banquets and religious festivals. Scenes depicting wine consumption were popular motifs in private tombs of the Eighteenth Dynasty (1539-1292 $\mathrm{BC})$ at Thebes. Furthermore, we also aim to document the scenes of wine-offering in rituals depicted in tombs and temples, as well as the archaeological artefacts (wine jars and related objects) which will be further included in the website. The expected results are to relate the process of wine elaboration of the ancient Egyptians to the traditional European 
method and to unveil the ancient Egyptian wine culture legacy in the Mediterranean through the compilation and study of the iconography, texts and artefacts.

\section{CONCLUSION}

The final and main result of the 'Irep en Kemet', Wine of ancient Egypt, project is to document the corpus of wine in ancient Egypt. At this stage, we are compiling and studying the viticulture and viticulture scenes in the Egyptian private tombs. Our goal is to publish an on-line comprehensive and researchable database of the viticulture and winemaking scenes in the ancient Egyptian tombs, considering all the data regarding the scene and the tomb where it was found, and the bibliographical references available. The database will be available on-line for Egyptologists, students or the public interested in this subject. In the near future, we plan to extend our project to include all the scenes related to wine in the ancient Egyptian daily life and rituals, depicted in temples and on funerary stelae and artefacts.

\section{REFERENCES}

Athenaeus (I, 33 d-f), 1961. Athenaeus, The Deipnosophists, with an English translation by Charles Burton Gulick, Loeb Classical library, Vol. I, London Harvard University Press, Cambridge-Massachusetts, Book, pp. 146-147.

Carter Archive: Tutankhamun: anatomy of an excavation, The Howard Carter Archives. The Griffith Institute, Oxford. http://www.griffith.ox.ac.uk (accessed 25 May 2012)

Černy, J., 1965. Wine jars. Baines J. (Ed.), Hieratic Inscriptions from the Tomb of Tutankhamun, Tutankhamun's Tomb Series, Vol. II, Griffith Institute, Oxford, Book, pp. 1-4.

Derchain, P., 1965. Le papyrus Salt 825 (B.M. 10051): Rituel pour la Conservation de la Vie en Égypte, Mémoires Vol. LVIII: 137 (II, 1), 147-149 (n. 10), Académie Royale de Belgique, Bruxelles, Book, pp. 137, 147-149.

Erman, A., Grapow, H., 1926. Irep. In: Wörterbuch der ägyptischen Sprache, Vol. IV, Akademie Verlag, Leipzig, p. 115 .

Erman, A., Grapow, H., 1930. Shedeh. In: Wörterbuch der ägyptischen Sprache, Vol. IV, Akademie Verlag, Leipzig, p. 568 .

Fonseca, S., Ibrahim, M., 2012. Documentation of viticulture and winemaking in the Egyptian tombs. In: Congress Jovens em Investigação Arqueológica (JIA) 2011 Proceeding, University of Faro, pp. 17-22.

Guasch-Jané, M.R. (et al.), 2004. Liquid chromatography mass spectrometry in tandem mode applied for the identification of wine markers in residues from ancient Egyptian vessels. Analytical Chemistry, 76, pp. 1672-1677.

Guasch-Jané, M.R. (et al.), 2006a. The origin of the ancient Egyptian drink shedeh revealed using LC/MS/MS. Journal of Archaeological Science, 33, pp. 98-101.
Guasch-Jané, M.R. (et al.), 2006b. First evidence of white wine in ancient Egypt from Tutankhamun's tomb. Journal of Archaeological Science, 33, pp. 1075-1080.

Guasch-Jané, M.R., 2008. Wine in Ancient Egypt: a Cultural and Analytical Study, British Archaeological Reports S1851, Archaeopress, Oxford, Book, pp. 11, 29-30, 53-54, 56-59.

Guasch-Jané, M.R., 2010. On Egyptian wine marketing, A. Hudecz, and M. Petrik (Ed.): Commerce and Economy in Ancient Egypt, Proceedings of the Third International Congress for Young Egyptologists 25-27 September 2009, Budapest. British Archaeological Reports S2131, Archaeopress, Oxford, pp. 63-69.

Guasch-Jané, M.R., 2011. The meaning of wine in Egyptian tombs: the three amphorae in Tutankhamun's burial chamber. Antiquity, 85(329), pp. 851-858.

James, L., 1996. The earliest history of wine and its importance in ancient Egypt. McGovern P.E., Fleming S.J., Katz S.H. (Eds.), The origins and ancient history of wine, Food and Nutrition in History and Anthropology, Vol. 11, Routledge, Amsterdam, Book, pp. 197-213.

Lesko, L., 1996. Egyptian wine production during the New Kingdom. McGovern P.E., Fleming S.J., Katz S.H. (Eds.), The origins and ancient history of wine, Food and Nutrition in History and Anthropology, Vol. 11, Routledge, Amsterdam, Book, pp. 215-230.

Lerstrup, A., 1992. The making of wine in Egypt. Göttinger Miszellen, 129, pp. 61-82.

Meyer, Ch., 1986. Wein. In: Lexikon der Ägyptologie, Vol. VI, Helck W., Westendorf W. (Eds.), Harrassowitz, Wiesbaden, pp. 1169-1182

Murray, A. M. (et al.), 2000. Viticulture and wine production. In: Nicholson, P.T., Shaw I. (Eds.), Ancient Egypt Materials and Technology, Cambridge University Press, Cambridge, Book, pp. 577- 608 .

Montet, P., 1913. La fabrication du vin dans les tombeaux antérieurs au nouvel empire. Recueil de Travaux Relatifs a la Philologie et a l'Archéologie Égyptiennes et Assyriennes, Vol. 35, Franck, Paris, Book, pp. 117-118.

Poo, M-Ch., 1995. Wine and wine offering in the religion of ancient Egypt. Helck W., Westendorf W. (Eds.), Kegan Paul Internacional, London, Book, pp. 149-151.

Poo, M-Ch., 1986. Weinopfer. In : Lexikon der Ägyptologie, Vol. VI, Helck W., Westendorf W. (Eds.), Harrassowitz, Wiesbaden, pp. 1186-1190.

Tallet, P., 1995. Le shedeh: etude d'un procédé de vinification en Égypte ancienne. BIFAO, 95, pp. 459-492.

Tallet, P., 1998. Le vin en Egypte à l'époque faraonique. Unpublished PhD, Université de Paris-Sorbonne, Paris, Book, pp. 356-397.

Tallet, P., 2010. De l'ivresse au dégrisement: à propos d'un article récent sur le vin shedeh. Göttinger Miszellen, 227, pp. 105-112. 


\section{ACKNOWLEDGEMENT}

This project «PTDC/HIS-ARQ/112562/2009» is financially supported by the Fundação para a Ciência e a Tecnologia (FCT), Ministério da Educação e Ciência in Portugal. 